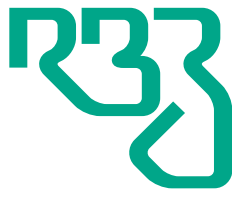

Brasileira de Zootecnia

Brazilian Journal of Animal Science ISSN 1806-9290

www.rbz.org.br

\title{
Nutritional value of distillers dried grains with solubles from corn and sorghum and xylanase in diets for pigs
}

\author{
Anderson Corassa $^{1^{*}}$ (D), Jessika Lucia Stuani ${ }^{1}$ (iD), Ana Paula Silva Ton ${ }^{1}$ (D), \\ Charles Kiefer $^{2}$ (ID), Maicon Sbardella ${ }^{1}$ (iD, Claudson Oliveira Brito ${ }^{3}$ (iD), \\ Alessandro Borges Amorim ${ }^{4}$ iD, Diésica Bianca Coelho Gonçalves ${ }^{1}$ iD \\ ${ }^{1}$ Universidade Federal de Mato Grosso, Instituto de Ciências Agrárias e Ambientais, Sinop, \\ MT, Brasil. \\ ${ }^{2}$ Universidade Federal de Mato Grosso do Sul, Faculdade de Medicina Veterinária e \\ Zootecnia, Campo Grande, MS, Brasil. \\ ${ }^{3}$ Universidade Federal de Sergipe, Departamento de Zootecnia, São Cristóvão, SE, Brasil. \\ ${ }^{4}$ Universidade Federal de Mato Grosso, Instituto de Ciências Agrárias e Tecnológicas, \\ Rondonópolis, MT, Brasil.
}

*Corresponding author: anderson_corassa@ufmt.br

Received: February 5, 2019 Accepted: June 21, 2019

How to cite: Corassa, A.; Stuani, J. L.; Ton, A. P. S.; Kiefer, C.; Sbardella, M.; Brito, C. O.; Amorim, A. B. and Gonçalves, D. B. C. 2019. Nutritional value of distillers dried grains with solubles from corn and sorghum and xylanase in diets for pigs. Revista Brasileira de Zootecnia 48:e20190012. https://doi.org/10.1590/rbz4820190012

Copyright: This is an open access article distributed under the terms of the Creative Commons Attribution License (http://creativecommons.org/licenses/by/4.0/) which permits unrestricted use, distribution, and reproduction in any medium, provided the original work is properly cited.
ABSTRACT - Two experiments were conducted to evaluate the digestibility and energy of distillers dried grains with solubles (DDGS) from corn and sorghum with or without xylanase enzyme in diets for pigs. The values of dry matter (DM), organic matter $(\mathrm{OM})$, crude protein $(\mathrm{CP})$, mineral matter $(\mathrm{MM})$, ether extract (EE), neutral detergent fiber (NDF), gross (GE), digestible (DE), metabolizable energy (ME), and digestibility coefficients (DC) were determined. In the experiment 1 , we used eight barrows of $26.15 \pm 3.45 \mathrm{~kg}$ with repeated measures in three periods of five days of collection. The treatments consisted of a reference diet (RD); RD with $200 \mathrm{~g} \mathrm{~kg}^{-1}$ corn DDGS or sorghum DDGS; and RD with $400 \mathrm{~g} \mathrm{~kg}^{-1}$ corn DDGS or sorghum DDGS. Corn DDGS showed higher values of DE, ME, and DC of EE, GE, and CP. Inclusions of $400 \mathrm{~g} \mathrm{~kg}^{-1}$ of the test ingredients resulted in higher values of DE and ME and trend for higher DC of DM, OM, and CP. In experiment 2, nine barrows weighing $34.91 \pm 1.46 \mathrm{~kg}$ were fed $\mathrm{RD}, 200 \mathrm{~g} \mathrm{~kg}^{-1}$ corn DDGS or $200 \mathrm{~g} \mathrm{~kg}^{-1}$ corn DDGS plus xylanase enzyme. The inclusion of xylanase did not influence the digestibility and energy values in diets containing corn DDGS. Values of DE and ME of corn DDGS were 3,477 and 3,277 kcal kg-1, respectively, for the substitution of $200 \mathrm{~g} \mathrm{~kg}^{-1}$ and 3,761 and 3,068 kcal kg-1 for the substitution of $400 \mathrm{~g} \mathrm{~kg}^{-1} \mathrm{RD}$. For sorghum DDGS, DE and ME values were 3,030 and 2,863 $\mathrm{kcal} \mathrm{kg}^{-1}$, respectively, for replacement of $200 \mathrm{~g} \mathrm{~kg}^{-1}$ and 3,398 and 3,296 kcal kg-1 for substitution of $400 \mathrm{~g} \mathrm{~kg}^{-1}$ RD. Levels of up to $400 \mathrm{~g} \mathrm{~kg}^{-1}$ do not influence the DE and ME of the diets but impair the digestibility coefficient of DM, OM, CP, EE, MM, and NDF. The use of xylanase enzyme in diets containing $200 \mathrm{~g} \mathrm{~kg}^{-1}$ of corn DDGS does not affect the digestibility of the diets.

Keywords: digestibility, DDGS, digestible energy, metabolizable energy

\section{Introduction}

With increasing ethanol production from corn in Brazil, the supply of distillers dried grains with solubles (DDGS) for inclusion in animal diets is growing. However, because the variability in composition and digestibility is directly related to the difference in the raw material composition and production process, it is necessary to know the nutrient and energy availability of these co-products for a precise formulation of diets for pigs. 
In the production of ethanol from corn and sorghum, grain starch is fermented, while fiber, protein, lipids, and minerals of the grain make up the DDGS. Variation in DDGS composition occurs due to genetic variation of the cereal source used (Belyea et al., 2010), variation in nitrogen fertilization, grain drying, presence of fungi, proportion of solubles added before drying (Li et al., 2015), among other factors.

Additionally, the inclusion level of DDGS as test ingredient in the digestibility experiments has ranged from 100 to $200 \mathrm{~g} \mathrm{~kg}^{-1}$ (Hanson et al., 2012); 150 and $250 \mathrm{~g} \mathrm{~kg}^{-1}$ (Lammers et al., 2015); $300 \mathrm{~g} \mathrm{~kg}^{-1}$ (Urriola et al., 2010); and 200, 400, and $600 \mathrm{~g} \mathrm{~kg}^{-1}$ DDGS (Corassa et al., 2017), and can be a source of variation in the determination of digestibility coefficients and energetic values.

The fiber of cereal grains is not converted into ethanol during the fermentation process, so diets containing DDGS could be supplemented with enzymes that hydrolyze non-starch polysaccharides (NSP) as a way of improving nutritional value (Swiatkiewicz et al., 2016). Expressive amounts of xylans and other NSP have been recorded in DDGS (Kim et al., 2008; Swiatkiewicz and Koreleski, 2007); however, the impact of the use of enzymes such as xylanase on nutrient digestibility has not been constant (Tsai et al., 2017).

These observations are consistent with the hypotheses that digestibility of DDGS from corn and sorghum differs according to the raw material, inclusion level used in the digestibility study, and use of xylanase.

The objectives of this study were to determine the digestibility coefficients and digestible and metabolizable energy values of corn and sorghum DDGS with different inclusion levels in the diet and determine the effect of xylanase enzyme on DDGS digestibility.

\section{Material and Methods}

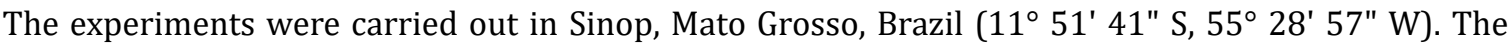
experimental procedures were approved by the local Ethics Committee on the Use of Animals, under case no. 23108.700673/14-4.

In experiment 1, eight barrows of the same genetic line, with initial mean weight of $26.15 \pm 3.45 \mathrm{~kg}$, were housed in metabolic cages, with repeated measures in three periods of five days of collection. The experiment was performed in a randomized block design using the weight of the animals to form the blocks, each animal being an experimental unit. The experiment consisted of five diets, with four replicates for the reference diet and five replicates for the other diets.

Before the onset of the experiment, the animals were adapted to the cages for two days, followed by three experimental periods constituting five days of feed intake followed by five days of total collection of feces and urine.

The experimental diets were a reference diet (RD) based on corn and soybean meal (Table 1) formulated to meet recommendations of Rostagno et al. (2011); $200 \mathrm{~g} \mathrm{~kg}^{-1}$ corn DDGS + $800 \mathrm{~g} \mathrm{~kg}^{-1} \mathrm{RD} ; 400 \mathrm{~g} \mathrm{~kg}^{-1}$ corn DDGS + $600 \mathrm{~g} \mathrm{~kg}^{-1} \mathrm{RD} ; 200 \mathrm{~g} \mathrm{~kg}^{-1}$ sorghum DDGS + $800 \mathrm{~g} \mathrm{~kg}^{-1} \mathrm{RD}$; and $400 \mathrm{~g} \mathrm{~kg}^{-1}$ sorghum DDGS + $600 \mathrm{~g} \mathrm{~kg}^{-1} \mathrm{RD}$, according to methodology of Sakomura and Rostagno (2016).

The DDGS came from an alcohol distillery (Libra Alcohol Distillery Ltda, São José do Rio Claro, MT, Brazil). The DDGS from corn contained $315.3 \mathrm{~g} \mathrm{~kg}^{-1}$ crude protein (CP), $4,949 \mathrm{kcal} \mathrm{kg}^{-1}$ gross energy (GE), $84.8 \mathrm{~g} \mathrm{~kg}^{-1}$ ether extract (EE), and $468.4 \mathrm{~g} \mathrm{~kg}^{-1}$ neutral detergent fiber (NDF). The DDGS from sorghum contained $260.9 \mathrm{~g} \mathrm{~kg}^{-1} \mathrm{CP}, 4,345 \mathrm{kcal} \mathrm{kg}^{-1} \mathrm{GE}, 82.1 \mathrm{~g} \mathrm{~kg}^{-1} \mathrm{EE}$, and $661.2 \mathrm{~g} \mathrm{~kg}^{-1} \mathrm{NDF}$.

The dry matter (DM), CP, mineral matter (MM), EE, NDF, and GE were determined to obtain the chemical composition of the diets (Table 2) and DDGS according to Silva and Queiroz (2002).

In the adaptation period, diets were given ad libitum, and leftovers were quantified. Diets were duly weighed and supplied twice a day $(07.30$ and $17.30 \mathrm{~h})$. From the data of feed intake during the 
adaptation period and based on the metabolic weight $\left(\mathrm{LW}^{0.60}\right)$, the amounts of feed given to each animal in the collection period were calculated according to the lower feed intake per kilogram of metabolic weight.

Fecal and urine collections were performed at $07.30 \mathrm{~h}$. Feces were collected, counted, weighed, homogenized, and then little samples of $200 \mathrm{~g} \mathrm{~kg}^{-1}$ of the total were stored in plastic bags, identified, and stored $\left(-10^{\circ} \mathrm{C}\right)$ until the end of the collection period.

The urine was filtered through a filter cloth coupled to the urine collecting box funnel and collected in plastic buckets with $10 \mathrm{~mL}$ of $1: 1 \mathrm{HCl}$. Total urine volume of each animal was measured through a $0.5-\mathrm{mL}$ graduated cylinder, from which $200 \mathrm{~mL} \mathrm{~L}^{-1}$ aliquots were taken and stored in a freezer.

After the sampling period, fecal samples were thawed and dried in a forced-ventilation oven at $60^{\circ} \mathrm{C}$ for $72 \mathrm{~h}$ to promote pre-drying for analytical determination of DM, CP, MM, EE, NDF, and GE, according to Silva and Queiroz (2002). The organic matter (OM) content was determined by the difference between the DM and MM contents. Total nitrogen and energy determination of urine were made from thawed and homogenized samples.

Table 1 - Composition and calculated nutritional values of the reference diet (as-fed basis)

\begin{tabular}{lc}
\hline Item & Reference diet \\
\hline Ingredient $\left(\mathrm{g} \mathrm{kg}^{-1}\right)$ & \\
Corn & 604.8 \\
Soybean meal & 302.6 \\
Rice bran & 30.0 \\
Soybean oil & 18.9 \\
Limestone & 5.2 \\
Dicalcium phosphate & 17.5 \\
Vitamin-trace mineral premix ${ }^{1}$ & 10.0 \\
Salt & 4.6 \\
L-lysine HCl & 1.5 \\
Chromium oxide & 5.0 \\
Total & 1000.0 \\
Calculated nutrient content $\left(\mathrm{g} \mathrm{kg}^{-1}\right)$ & \\
Metabolizable energy $\left({\left.\mathrm{kcal} \mathrm{kg}^{-1}\right)}_{\text {Crude protein }}\right.$ & 3,230 \\
Calcium & 189.9 \\
Available phosphorus & 7.2 \\
Sodium & 3.6 \\
Digestible lysine & 2.0 \\
\hline
\end{tabular}

${ }^{1}$ Provided per kg of diet: vitamin A, 13,750 IU; vitamin B1, 2 mg; vitamin B2, 1.25 mg; vitamin B6, 4 mg; vitamin B12, 4.5 mcg; vitamin D3, $3000 \mathrm{IU}$; vitamin E, $75 \mathrm{IU}$; vitamin $\mathrm{K} 3,6.25 \mathrm{mg}$; nicotinic acid, $50 \mathrm{mg}$; pantothenic acid, $30 \mathrm{mg}$; folic acid, $0.625 \mathrm{mg}$; cobalto, $1.25 \mathrm{mg}$; copper $25 \mathrm{mg}$; iron, $150 \mathrm{mg}$; zinc, $200 \mathrm{mg}$; manganese, $75 \mathrm{mg}$; selenium, $0.7 \mathrm{mg}$; iodine, $2 \mathrm{mg}$; coline, $250 \mathrm{mg}$; biotin, $25 \mathrm{mcg}$.

Table 2 - Chemical composition of dietary treatments ( $\mathrm{g} \mathrm{kg}^{-1}$, dry-matter basis)

\begin{tabular}{|c|c|c|c|c|c|}
\hline \multirow{2}{*}{ Item } & \multirow{2}{*}{$\mathrm{RD}$} & \multicolumn{2}{|c|}{ Corn DDGS } & \multicolumn{2}{|c|}{ Sorghum DDGS } \\
\hline & & 200 & 400 & 200 & 400 \\
\hline Dry matter & 955 & 956 & 946 & 957 & 953 \\
\hline Organic matter & 935 & 943 & 956 & 945 & 954 \\
\hline Crude protein & 173 & 178 & 210 & 177 & 194 \\
\hline Ether extract & 79 & 81 & 82 & 72 & 64 \\
\hline Mineral matter & 66 & 57 & 44 & 55 & 46 \\
\hline Neutral detergent fiber & 430 & 450 & 460 & 470 & 500 \\
\hline Gross energy $\left(\mathrm{kcal} \mathrm{kg}^{-1}\right)$ & 4,198 & 4,321 & 4,489 & 4,287 & 4,425 \\
\hline
\end{tabular}

RD - reference diet; DDGS - distillers dried grains with solubles. 
The apparent total tract digestibility (DC) and metabolizability coefficients (MC), digestible nutrient contents, and digestible and metabolizable energy values were determined based on the methodology of Sakomura and Rostagno (2016).

The experiment was conducted in a $2 \times 2+1$ factorial completely randomized block design, with two sources of DDGS (corn and sorghum), two inclusion levels of DDGS (200 and $400 \mathrm{~g} \mathrm{~kg}^{-1}$ ), and one reference diet. The results were tested by analysis of variance, and the effects broken down into three orthogonal contrasts: $1=$ reference diet versus other diets, $2=$ corn DDGS versus sorghum DDGS, and $3=200 \mathrm{~g} \mathrm{~kg}^{-1}$ versus $400 \mathrm{~g} \mathrm{~kg}^{-1}$ of DDGS inclusion. The statistical model used was:

$$
Y_{i j k}=\mu+S_{i}+L_{j}+B_{k}+S_{i} \times L_{j}+\varepsilon_{i j k^{\prime}}
$$

in which $Y_{\mathrm{ijk}}=$ observation referring to the effect source $_{\mathrm{i}}$ of DDGS, at level ${ }_{\mathrm{j}}$ of DDGS, to block $\mathrm{k}_{\mathrm{k}} ; \mu=$ overall mean; $\mathrm{S}_{\mathrm{i}}=$ source (corn or sorghum DDGS); $\mathrm{L}_{\mathrm{j}}=$ inclusion level of DDGS (200 or $400 \mathrm{~g} \mathrm{~kg}^{-1}$ ); $\mathrm{B}_{\mathrm{k}}=$ block; $\mathrm{S}_{\mathrm{i}} \times \mathrm{L}_{\mathrm{j}}=$ interaction between sources and levels; and $\varepsilon_{\mathrm{ijk}}=$ random error associated with source and level. The Mixed procedure of SAS (Statistical Analysis System, version 6.0) was used considering $<0.05$ as significance level and 0.10 as a trend of significance.

In experiment 2, nine barrows of the same genetic line and with an initial mean weight of $34.91 \pm 1.46 \mathrm{~kg}$ were individually distributed in metabolic cages. The experiment was performed in a randomized block design, consisting of three treatments and three replicates, each animal being an experimental unit. The animals were housed in metabolic cages with seven days for adaptation to diets and cages and five days for data collection, comprising a total period of twelve days. The experimental procedures were identical to those adopted in experiment 1.

The treatments consisted of a RD based on corn and soybean meal (Table 1), made to meet the recommendations of Rostagno et al. (2011); $200 \mathrm{~g} \mathrm{~kg}^{-1}$ corn DDGS + $800 \mathrm{~g} \mathrm{~kg}^{-1} \mathrm{RD}$; and $200 \mathrm{~g} \mathrm{~kg}^{-1}$ corn DDGS $+800 \mathrm{~g} \mathrm{~kg}^{-1} \mathrm{RD}+0.1 \mathrm{~g} \mathrm{~kg}^{-1}$ xylanase $\left(16,000 \mathrm{BXU} \mathrm{kg}{ }^{-1}\right)$.

The statistical model used was

$$
\mathrm{Y}_{\mathrm{ijk}}=\mu+\mathrm{D}_{\mathrm{i}}+\mathrm{X}_{\mathrm{j}}+\varepsilon_{\mathrm{ij} \mathrm{k}^{\prime}}
$$

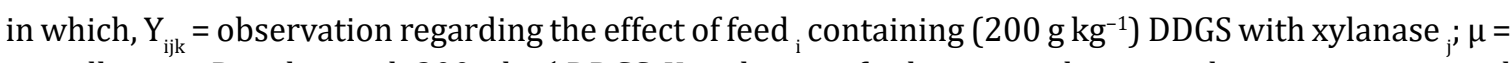
overall mean; $\mathrm{Di}=$ diet with $200 \mathrm{~g} \mathrm{~kg}^{-1} \mathrm{DDGS}, \mathrm{X}_{\mathrm{j}}$ inclusion of xylanase; and $\varepsilon_{\mathrm{ijk}}=$ random error associated with DDGS and xylanase. The Mixed procedure of SAS was used considering $<0.05$ as significance level and 0.10 as a trend of significance.

\section{Results}

There was no interaction effect between source and inclusion level for the variables under study, except for CP and EE digestibility. Pigs fed RD expressed the highest values of DE, DC, ME, and MC in comparison with pigs fed the other diets, while those receiving diets with corn DDGS also expressed

\begin{tabular}{|c|c|c|c|c|c|c|c|c|c|c|}
\hline \multirow[b]{2}{*}{ Item } & \multirow[b]{2}{*}{$\mathrm{RD}$} & \multicolumn{2}{|c|}{ Corn DDGS $\left(\mathrm{g} \mathrm{kg}^{-1}\right)$} & \multicolumn{2}{|c|}{ Sorghum DDGS $\left(\mathrm{g} \mathrm{kg}^{-1}\right)$} & \multicolumn{4}{|c|}{ Significance } & \multirow[b]{2}{*}{ SEM } \\
\hline & & 200 & 400 & 200 & 400 & $\begin{array}{l}\text { RD vs } \\
\text { others }\end{array}$ & $\begin{array}{c}\text { Source } \\
\text { (S) }\end{array}$ & $\begin{array}{l}\text { Level } \\
\text { (L) }\end{array}$ & $S \times L$ & \\
\hline $\mathrm{GE}\left(\mathrm{kcal} \mathrm{kg}^{-1}\right)$ & 4,198 & 4,321 & 4,489 & 4,287 & 4,425 & - & - & - & - & \\
\hline $\mathrm{DE}\left(\mathrm{kcal} \mathrm{kg}{ }^{-1}\right)$ & 3,809 & 3,752 & 3,805 & 3,673 & 3,667 & 0.0112 & 0.0003 & 0.3497 & 0.3986 & 25.2 \\
\hline $\mathrm{DC}\left(\mathrm{g} \mathrm{kg}^{-1}\right)$ & 907 & 868 & 847.6 & 856 & 828 & $<0.0001$ & 0.0132 & 0.0003 & 0.5976 & 5.65 \\
\hline ME (kcal kg-1) & 3,702 & 3,625 & 3,679 & 3,554 & 3,559 & 0.0130 & 0.0042 & 0.3181 & 0.5305 & 29.8 \\
\hline $\mathrm{MC}\left(\mathrm{g} \mathrm{kg}^{-1}\right)$ & 882 & 839 & 819 & 829 & 804 & $<0.0001$ & 0.0681 & 0.0034 & 0.7083 & 6.65 \\
\hline DE- DDGS (kcal kg-1) & - & 3,477 & 3,761 & 3,030 & 3,398 & - & 0.0004 & 0.0028 & 0.7173 & 94.2 \\
\hline ME- DDGS $\left(\mathrm{kcal} \mathrm{kg}^{-1}\right)$ & - & 3,277 & 3,609 & 2,863 & 3,296 & - & 0.0007 & 0.0004 & 0.7185 & 88.5 \\
\hline
\end{tabular}

Table 3 - Energy diet values with different levels and sources of DDGS for pigs (Exp. 1)

RD - reference diet; DDGS - distillers dried grains with solubles; GE - gross energy; DE - digestible energy; DC - digestibility coefficient; ME metabolizable energy; MC - metabolizability coefficient; SEM - standard error of the mean. 
superiority in these parameters and trend $(\mathrm{P}=0.0681)$ for higher $\mathrm{MC}$ compared with animals fed sorghum DDGS (Table 3). The inclusion level of $200 \mathrm{~g} \mathrm{~kg}^{-1}$ of DDGS presented higher values of DC and MC compared with the $400 \mathrm{~g} \mathrm{~kg}^{-1}$ level, but ME and DE were not influenced.

We observed higher DC of EE, GE, and CP in corn DDGS compared with sorghum DDGS, while the $400 \mathrm{~g} \mathrm{~kg}^{-1}$ level expressed higher DC of NDF and GE compared with the $200 \mathrm{~g} \mathrm{~kg}^{-1}$ inclusion level (Table 4).

The RD had higher DC values for DM, OM, CP, EE, MM, and NDF compared with the other diets (Table 5). Diets containing inclusion of corn DDGS generated higher DC values for CP and EE but did not differ in DM, OM, and MM compared with those containing sorghum DDGS. Diets containing sorghum DDGS had higher DC values for NDF compared with those with corn DDGS. The inclusion of $200 \mathrm{~g} \mathrm{~kg}^{-1}$ DDGS in the diets generated higher DC values in all the parameters of the diets compared with the $400 \mathrm{~g} \mathrm{~kg}^{-1}$ inclusion.

Table 4 - Apparent total tract digestibility coefficients of corn and sorghum DDGS for pigs with different DDGS levels (Exp. 1)

\begin{tabular}{|c|c|c|c|c|c|c|c|c|}
\hline \multirow{2}{*}{$\begin{array}{l}\text { Digestibility coefficient } \\
\left(\mathrm{g} \mathrm{kg}^{-1}\right)\end{array}$} & \multicolumn{2}{|c|}{ Corn DDGS } & \multicolumn{2}{|c|}{ Sorghum DDGS } & \multicolumn{3}{|c|}{ Significance } & \multirow{2}{*}{ SEM } \\
\hline & 200 & 400 & 200 & 400 & Source (S) & Level (L) & $S \times L$ & \\
\hline Dry matter & 712 & 745 & 666 & 719 & 0.1271 & 0.0700 & 0.6740 & 26.7 \\
\hline Organic matter & 714 & 747 & 668 & 722 & 0.1164 & 0.0552 & 0.6416 & 25.8 \\
\hline Crude protein & 825 & 863 & 573 & 669 & $<0.0001$ & 0.0539 & 0.3895 & 39.1 \\
\hline Ether extract & 730 & 750 & 579 & 603 & 0.0020 & 0.5956 & 0.9902 & 49.8 \\
\hline Mineral matter & 587 & 582 & 533 & 553 & 0.3633 & 0.8679 & 0.7880 & 53.7 \\
\hline Neutral detergent fiber & 600 & 661 & 644 & 704 & 0.1004 & 0.0262 & 0.9920 & 30.1 \\
\hline Gross energy & 703 & 752 & 632 & 699 & 0.0122 & 0.0167 & 0.7060 & 26.6 \\
\hline
\end{tabular}

DDGS - distillers dried grains with solubles; SEM - standard error of the mean.

Table 5 - Apparent total tract digestibility coefficients of the experimental diets for pigs with different DDGS sources and levels (Exp. 1)

\begin{tabular}{|c|c|c|c|c|c|c|c|c|c|c|}
\hline \multirow{2}{*}{$\begin{array}{l}\text { Digestibility coefficient } \\
\left(\mathrm{g} \mathrm{kg}^{-1}\right)\end{array}$} & \multirow{2}{*}{$\mathrm{RD}$} & \multicolumn{2}{|c|}{ Corn DDGS } & \multicolumn{2}{|c|}{ Sorghum DDGS } & \multicolumn{4}{|c|}{ Significance } & \multirow{2}{*}{ SEM } \\
\hline & & 200 & 400 & 200 & 400 & RD vs others & Source $(S)$ & Level (L) & $\mathrm{S} \times \mathrm{L}$ & \\
\hline Dry matter & 907 & 870 & 844 & 864 & 836 & $<0.0001$ & 0.1972 & $<0.0001$ & 0.8094 & 5.42 \\
\hline Organic matter & 915 & 877 & 850 & 870 & 843 & $<0.0001$ & 0.1782 & $<0.0001$ & 0.8323 & 5.25 \\
\hline Crude protein & 904 & 884 & 878 & 836 & 804 & $<0.0001$ & $<0.0001$ & 0.0326 & 0.1560 & 8.55 \\
\hline Ether extract & 901 & 875 & 857 & 849 & 800 & 0.0004 & 0.0008 & 0.0052 & 0.2960 & 10.6 \\
\hline Mineral matter & 796 & 755 & 712 & 751 & 704 & $<0.0001$ & 0.5972 & 0.0006 & 0.8178 & 11.2 \\
\hline Neutral detergent fiber & 919 & 856 & 816 & 867 & 836 & $<0.0001$ & 0.0364 & $<0.0001$ & 0.7548 & 6.80 \\
\hline
\end{tabular}

RD - reference diet; DDGS - distillers dried grains with solubles; SEM - standard error of the mean.

Table 6 - Apparent total tract digestibility content of the experimental diets for pigs with different DDGS sources and levels (Exp. 1)

\begin{tabular}{|c|c|c|c|c|c|c|c|c|c|c|}
\hline \multirow{2}{*}{$\begin{array}{l}\text { Digestibility content } \\
\left(\mathrm{g} \mathrm{kg}^{-1}\right)\end{array}$} & \multirow{2}{*}{$\mathrm{RD}$} & \multicolumn{2}{|c|}{ Corn DDGS } & \multicolumn{2}{|c|}{ Sorghum DDGS } & \multicolumn{4}{|c|}{ Significance } & \multirow{2}{*}{ SEM } \\
\hline & & 200 & 400 & 200 & 400 & RD vs others & Source $(S)$ & Level (L) & $\mathrm{S} \times \mathrm{L}$ & \\
\hline Dry matter & 866 & 832 & 799 & 826 & 797 & $<0.0001$ & 0.5015 & $<0.0001$ & 0.9737 & 5.16 \\
\hline Organic matter & 856 & 827 & 813 & 822 & 804 & $<0.0001$ & 0.1904 & 0.0043 & 0.6819 & 5.02 \\
\hline Crude protein & 157 & 158 & 184 & 148 & 156 & 0.0221 & $<0.0001$ & $<0.0001$ & 0.2503 & 1.64 \\
\hline Ether extract & 72 & 71 & 70 & 61 & 51 & $<0.0001$ & $<0.0001$ & $<0.0001$ & 0.3705 & 0.77 \\
\hline Mineral matter & 52 & 43 & 31 & 41 & 32 & $<0.0001$ & 0.4399 & $<0.0001$ & 0.1548 & 0.51 \\
\hline Neutral detergent fiber & 395 & 385 & 375 & 407 & 418 & 0.7216 & $<0.0001$ & 0.9464 & 0.0557 & 3.24 \\
\hline
\end{tabular}

RD - reference diet; DDGS - distillers dried grains with solubles; SEM - standard error of the mean. 
The RD presented higher values of digestible fractions of DM, EE, CP, MM, and OM compared with the other diets but did not differed as to the digestible NDF content (Table 6). The digestible fractions of DM, OM, and MM of the experimental diets were not influenced by DDGS source; however, CP and EE values were higher for diets containing corn DDGS compared with those with sorghum DDGS, whereas digestible NDF data showed an inverse behavior (Table 6). The inclusion of $200 \mathrm{~g} \mathrm{~kg}^{-1} \mathrm{DDGS}$ resulted in higher values of digestible fractions of DM, OM, MM, and EE compared with the $400 \mathrm{~g} \mathrm{~kg}^{-1}$ inclusion, data of digestible CP presented an inverse behavior but did not change values of digestible NDF.

The DDGS values of DE and ME were not influenced by the inclusion of xylanase. Values of energy, digestibility coefficients, and digestible fractions of the diets were not influenced by the treatments (Tables 7, 8, and 9). However, a higher digestible MM value was found for RD compared with the other diets (Table 9).

Table 7 - Energy values of diets with DDGS and xylanase (XYL) for pigs (Exp. 2)

\begin{tabular}{lccccc}
\hline Item & RD & Corn DDGS & Corn DDGS + XYL & Significance & SEM \\
\hline Gross energy $\left(\mathrm{kcal} \mathrm{kg}^{-1}\right)$ & 4,198 & 4,321 & 4,349 & - & - \\
Digestible energy $\left(\mathrm{DE} ; \mathrm{kcal} \mathrm{kg}^{-1}\right)$ & 3,897 & 3,922 & 3,921 & 0.9033 & 25.5 \\
Digestibility coefficient $\left(\mathrm{g} \mathrm{kg}^{-1}\right)$ & 928 & 908 & 901 & 0.2353 & 5.94 \\
Metabolizable energy $\left(\mathrm{ME} ; \mathrm{kcal} \mathrm{kg}^{-1}\right)$ & 3,769 & 3,753 & 3,761 & 0.9653 & 25.5 \\
Metabolizability coefficient $\left(\mathrm{g} \mathrm{kg}^{-1}\right)$ & 898 & 868 & 865 & 0.1162 & 5.94 \\
DE- DDGS $\left(\mathrm{kcal} \mathrm{kg}^{-1}\right)$ & - & 4,021 & 4,019 & 0.9770 & 145.3 \\
ME- DDGS $\left(\mathrm{kcal} \mathrm{kg}^{-1}\right)$ & - & 3,686 & 3,728 & 0.9890 & 147.8 \\
\hline
\end{tabular}

RD - reference diet; DDGS - distillers dried grains with solubles; SEM - standard error of the mean.

Table 8 - Apparent total tract digestibility coefficients of the experimental diets for pigs with DDGS and xylanase (XYL) (Exp. 2)

\begin{tabular}{lccccc}
\hline Digestibility coefficient $\left(\mathrm{g} \mathrm{kg}^{-1}\right)$ & RD & Corn DDGS & Corn DDGS + XYL & Significance & SEM \\
\hline Dry matter & 929 & 909 & 904 & 0.2444 & 5.83 \\
Organic matter & 935 & 913 & 909 & 0.1963 & 5.54 \\
Crude protein & 930 & 913 & 908 & 0.4098 & 6.54 \\
Ether extract & 929 & 917 & 910 & 0.6714 & 8.43 \\
Mineral matter & 853 & 842 & 830 & 0.6868 & 10.6 \\
Neutral detergent fiber & 929 & 895 & 886 & 0.0841 & 6.73 \\
\hline
\end{tabular}

RD - reference diet; DDGS - distillers dried grains with solubles; SEM - standard error of the mean.

Table 9 - Apparent total tract digestibility content of the experimental diets for pigs with DDGS and xylanase (XYL) (Exp. 2)

\begin{tabular}{lccccc}
\hline Digestibility content $\left(\mathrm{g} \mathrm{kg}^{-1}\right)$ & RD & Corn DDGS & Corn DDGS + XYL & Significance & SEM \\
\hline Dry matter & 887 & 869 & 862 & 0.2416 & 5.54 \\
Organic matter & 876 & 861 & 860 & 5.43 \\
Crude protein & 161 & 163 & 162 & 0.8584 & 1.13 \\
Ether extract & 74 & 74 & 74 & 0.9144 \\
Mineral matter & $56 \mathrm{a}$ & $48 \mathrm{~b}$ & $47 \mathrm{~b}$ & 0.0020 \\
Neutral detergent fiber & 399 & 403 & 399 & 0.8567 & 0.63 \\
\hline
\end{tabular}

RD - reference diet; DDGS - distillers dried grains with solubles; SEM - standard error of the mean. Means in the same row followed by different letters differ from each other by the Tukey test $(\mathrm{P}<0.05)$. 


\section{Discussion}

The Brazilian corn DDGS of this study show the gross energy value $\left(4,949 \mathrm{kcal} \mathrm{kg}^{-1}\right)$ lower than the mean values reported by Anderson et al. (2012) (5,076 to 5,550 $\left.\mathrm{kcal} \mathrm{kg}^{-1}\right)$ but close to other Brazilian DDGS analyzed by Corassa et al. (2017) $\left(4,780 \mathrm{kcal} \mathrm{kg}^{-1}\right)$. The gross energy of sorghum DDGS evaluated in this study $\left(4,345 \mathrm{kcal} \mathrm{kg}^{-1}\right)$ was lower than in the samples evaluated by Jacela et al. (2010) $\left(5,108 \mathrm{kcal} \mathrm{kg}^{-1}\right)$ and by Stein et al. (2016) $\left(5,302 \mathrm{kcal} \mathrm{kg}^{-1}\right)$. Values of DE and ME determined for corn DDGS were higher than those of sorghum DDGS, which was also evidenced by Feoli et al. (2008) and are related to higher DC of CP, EE, and GE. Characteristics of the grains used as raw material may have influenced the composition of the co-product, and corn has higher energy value compared with sorghum.

The energy content of pig feed is closely related to its chemical composition. Analyzing the ether extract of the corn and sorghum DDGS, values of 84.8 and $82.1 \mathrm{~g} \mathrm{~kg}^{-1}$, respectively, were observed, justifying the difference in the energy value between the sources. The Brazilian DDGS of this study present average oil content, based on NRC (2012) classification that considers $>100 \mathrm{~g} \mathrm{~kg}^{-1}$ as high, 60 to $90 \mathrm{~g} \mathrm{~kg}^{-1}$ as medium, and $<40 \mathrm{~g} \mathrm{~kg}^{-1}$ as low oil content. The oil content of DDGS is an important variable, because it was related to differences in growth performance of pigs (Graham et al., 2014).

On the other hand, it is well established that dietary fiber negatively affects energy and nutrient utilization by pigs and results in increased fecal output and nutrient excretion (Urriola et al., 2010). The increase in the levels of insoluble fiber in the diet increases the rate of passage of the digesta through the gastrointestinal tract (GIT) and can be due to the physical stimulation of the insoluble fiber on the GIT walls. Therefore, the action of microorganisms on these fibers in the small intestine can create a physical barrier to the performance of certain digestive enzymes, reducing the diet digestibility (Silva, 2015).

The reduction in DC (Table 7) and the digestible fraction (Table 8) of OM, DM, MM, NDF, and EE with increasing DDGS inclusion is probably related to the fiber fraction in the tested ingredients, in which this concentration is almost three times higher than that of the original grains (Pedersen et al., 2014). Quantities above $600 \mathrm{~g} \mathrm{~kg}^{-1}$ NDF were observed in the DDGS of the present study, contributing to differences in DDGS energy digestibility as also observed by Corassa et al. (2017) and Anderson et al. (2012).

The use of high fiber content in pig diets may be a critical factor, especially when given to animals that do not possess a suitable GIT. Nevertheless, fiber can cause deleterious effects on the digestibility coefficients of nutrients, and Gomes et al. (2007) concluded that fibrous diets can promote changes in the absorption rate of nutrients, especially amino acids and minerals. Moreover, the dietary fiber concentration may also affect feed intake, since the increase in fiber content may limit the physical ability of the intestines to digest more feed (Wu et al., 2016).

The observation of higher NDF content in sorghum DDGS compared with corn DDGS in this study corroborates the results of Sotak et al. (2014). However, regardless of the source, it was observed that DDGS inclusion in the diets resulted in an increase in NDF content and worsening in diet DC compared with the diet with corn and soybean meal. The present results are similar to a study that evaluated inclusions of 200, 400, and $600 \mathrm{~g} \mathrm{~kg}^{-1}$ of corn DDGS and reported a decline in the DC of NDF as the DDGS inclusion increased (Corassa et al., 2017).

The results of this study also show the influence of the inclusion level of the tested feeds on the determination of the digestibility. The higher DC values of NDF and GE and the tendency for DM, OM, and CP presented in the two DDGS sources with $400 \mathrm{~g} \mathrm{~kg}^{-1}$ inclusion compared with the $200 \mathrm{~g} \mathrm{~kg}^{-1}$ inclusion suggest that the higher use of this feed, the greater its inclusion. In this sense, Sakomura and Rostagno (2016) inferred that the higher the proportion of feed in the test diet, the greater the precision in the determination, as long as the characteristics of the ingredients are respected.

When considering the reduction in the digestibility of diets and improvement in the DC of DDGS with higher inclusions of the test ingredient, it is understood that the magnitude of the differences of DC between the diets was smaller than the magnitude of the differences between the inclusion levels of the 
test ingredient. This is due to the calculation method of DC, which considers the difference between the $\mathrm{DC}$ of the test diet and the RD, dividing it by the inclusion level of the test ingredient, adding this value to the $\mathrm{DC}$ of the RD. This same calculation is used to determine the digestible and metabolizable energy value according to Sakomura and Rostagno (2016).

The effect of the inclusion level of the test ingredient on the digestibility was also reported by Bolarinwa and Adeola (2016), who evaluated the diets with barley and wheat at levels of 0,300 , and $600 \mathrm{~g} \mathrm{~kg}^{-1}$, and observed a decreasing linear effect in values of DE and ME and DC of DM for barley. However, Verussa et al. (2017) observed that the DC of OM and DM increased linearly as the inclusion of glycerin increased with 50, 100, and $150 \mathrm{~g} \mathrm{~kg}^{-1}$. Inclusion levels of 200, 400, and $600 \mathrm{~g} \mathrm{~kg}^{-1}$ corn DDGS tested by Corassa et al. (2017) resulted in differences in DC and digestible fractions of the diet due to DDGS inclusions. In any case, the differences between the studies are related to the characteristics of the evaluated ingredients.

The DM digestibility values of the diets containing $200 \mathrm{~g} \mathrm{~kg}^{-1}$ DDGS were higher than the values reported by Urriola et al. (2010) using $300 \mathrm{~g} \mathrm{~kg}^{-1}$ inclusion but close to those of Hanson et al. (2012), who used 100 and $200 \mathrm{~g} \mathrm{~kg}^{-1}$ inclusion, suggesting that high levels of DDGS can reduce DM digestibility of the diets. Dietary fiber negatively affects DE and ME and nutrient utilization by pigs, resulting in increased fecal output and nutrient excretion (Noblet and Shi, 1994). The concentration of fiber and other chemical components in DDGS observed in the experiments is mainly due to the difference in the composition of the original grains used to produce ethanol (NRC, 2012). However, the observation of equality of DC of NDF between corn and sorghum DDGS (Table 4), together with the difference in this parameter in the diets containing the two sources (Table 5), suggest that the chemical constitutions of this fiber fraction of both are close and that differences between the sources are quantitative.

The addition of xylanase enzyme in a diet containing DDGS did not affect any of the parameters of digestibility and energy values evaluated in this study, contrary to the initial hypothesis. Similar to the present study, Jones et al. (2010) evaluated xylanase levels in diets based on corn and soybean meal and with $300 \mathrm{~g} \mathrm{~kg}^{-1}$ corn DDGS to pigs and concluded that xylanase supplementation did not alter the energy performance and digestibility coefficient of the diets. Moreover, Moran et al. (2016) stated that xylanase supplementation had limited potential to enhance nutrient digestibility of pigs fed DDGS-based diets. In this sense, Weiland and Patience (2016), evaluating 0 and $300 \mathrm{~g} \mathrm{~kg}^{-1}$ DDGS and 0 and $4 \mathrm{~g} \mathrm{~kg}^{-1}$ xylanase, observed that DDGS decreased DM digestibility, and xylanase inclusion did not significantly impact DM digestibility or DE value of the diet for pigs at $46 \mathrm{~kg}$ body weight; however, at $70 \mathrm{~kg}$, xylanase inclusion increased DM digestibility, concluding that xylanase did not affect DM digestibility or DE in the smallest pigs and improved both in the heaviest pigs.

Nevertheless, Ndou et al. (2015) observed a reduction of negative impacts on nutrient digestibility when compared with the control diet without the enzyme in diets with $300 \mathrm{~g} \mathrm{~kg}^{-1}$ DDGS. Likewise, Tsai et al. (2017) observed increased DM, NDF, acid detergent fiber, and hemicellulose digestibility when using xylanase in diets containing $300 \mathrm{~g} \mathrm{~kg}^{-1}$ corn DDGS, while Barnes et al. (2011) found that xylanase addition increased apparent fecal ADF digestibility of growing-finishing pigs fed diets with 150 or $300 \mathrm{~g} \mathrm{~kg}^{-1}$ corn DDGS.

The results of research on enzymes are often contradictory, but adequacy of factors such as amount of substrate and adequate dosage of enzymes has been suggested (Jones et al., 2010) to evidence biologically favorable responses. However, few studies quantified the content of fiber fraction in corn DDGS, registering $160 \mathrm{~g} \mathrm{~kg}^{-1}$ cellulose, $80 \mathrm{~g} \mathrm{~kg}^{-1}$ xylan, $50 \mathrm{~g} \mathrm{~kg}^{-1}$ arabinan (Kim et al., 2008), $265 \mathrm{~g} \mathrm{~kg}^{-1}$ total NSP (35.5 g kg${ }^{-1}$ soluble and $235 \mathrm{~g} \mathrm{~kg}^{-1}$ insoluble NSP), and $215 \mathrm{~g} \mathrm{~kg}^{-1}$ arabinoxylans, and $3.2 \mathrm{~g} \mathrm{~kg}^{-1}$ $\beta$-glucans (Swiatkiewicz and Koreleski, 2007).

In a recent review, Swiatkiewicz et al. (2016) stated that the efficacy of enzymes used in pig diets with DDGS is not consistent and that factors such as activity of the enzymes used, age and physiological stage of the animals, level of DDGS used, chemical composition, and composition of diets can influence. According to these authors, the use of xylanase alone without the use of other exogenous enzymes such as proteases, amylase, and beta-glucanase does not produce a response similar to those obtained with 
a combination of the enzymes. However, Kerr et al. (2013) showed a small and inconsistent effect on nutrient digestibility using mixtures of commercial NSP-containing enzymes, and none of the products improved performance of pigs fed diets with $300 \mathrm{~g} \mathrm{~kg}^{-1}$ corn DDGS. Therefore, further studies evaluating the use of enzymes should be carried out to improve the digestibility of DDGS-containing diets.

The lowest concentration of MM in DDGS-containing diets is due to the isomeric substitution method of the RD with the test ingredient used in this study, since $200 \mathrm{~g} \mathrm{~kg}^{-1}$ of the RD with the highest concentration of minerals is withdrawn compared with the test ingredient added.

\section{Conclusions}

Metabolizable energy of corn distillers dried grains with solubles is 3,277 and 3,609 $\mathrm{kcal} \mathrm{kg}^{-1}$ and 3,296 and 2,863 kcal kg-1 of sorghum distillers dried grains with solubles with 200 and $400 \mathrm{~g} \mathrm{~kg}^{-1}$ inclusion, respectively.

Levels up to $400 \mathrm{~g} \mathrm{~kg}^{-1}$ do not influence the digestible and metabolizable energy of the diets but impair the digestibility coefficient of organic matter, dry matter, ether extract, crude protein, neutral detergent fiber, and mineral matter.

Corn distillers dried grains with solubles show better digestibility than sorghum distillers dried grains with solubles, while $200 \mathrm{~g} \mathrm{~kg}^{-1}$ inclusion indicate better digestibility coefficients than $400 \mathrm{~g} \mathrm{~kg}^{-1}$.

The use of xylanase enzyme in diets containing $200 \mathrm{~g} \mathrm{~kg}^{-1}$ distillers dried grains with solubles does not affect the digestibility of the diets.

\section{Conflict of Interest}

The authors declare no conflict of interest.

\section{Author Contributions}

Conceptualization: A. Corassa and A.P.S. Ton. Data curation: A. Corassa, J.L. Stuani, A.P.S. Ton, M. Sbardella and D.B.C. Gonçalves. Formal analysis: A. Corassa, J.L. Stuani, A.P.S. Ton, C. Kiefer, M. Sbardella, C.O. Brito, A.B. Amorim and D.B.C. Gonçalves. Funding acquisition: A. Corassa, A.P.S. Ton and M. Sbardella. Investigation: A. Corassa, J.L. Stuani, A.P.S. Ton, C. Kiefer, M. Sbardella, C.O. Brito, A.B. Amorim and D.B.C. Gonçalves. Methodology: A. Corassa, J.L. Stuani, A.P.S. Ton, C. Kiefer, M. Sbardella, C.O. Brito, A.B. Amorim and D.B.C. Gonçalves. Project administration: A. Corassa, J.L. Stuani, M. Sbardella, C.O. Brito and A.B. Amorim. Resources: A. Corassa. Software: A. Corassa. Supervision: A. Corassa. Validation: A. Corassa and C. Kiefer. Visualization: A. Corassa and C. Kiefer. Writing-original draft: A. Corassa, J.L. Stuani, A.P.S. Ton, C. Kiefer, M. Sbardella, C.O. Brito and A.B. Amorim. Writing-review \& editing: A. Corassa, A.P.S. Ton, C. Kiefer, M. Sbardella, C.O. Brito and A.B. Amorim.

\section{Acknowledgments}

The authors thank the Coordenação de Aperfeiçoamento de Pessoal de Nível Superior (CAPES) for the scholarship granted to the second author, and Fundação de Amparo à Pesquisa do Estado de Mato Grosso, for funding this research.

\section{References}

Anderson, P. V.; Kerr, B. J.; Weber, T. E.; Ziemer, C. J. and Shurson, G. C. 2012. Determination and prediction of digestible and metabolizable energy from chemical analysis of corn coproducts fed to finishing pigs. Journal of Animal Science 90:1242-1254. https://doi.org/10.2527/jas.2010-3605

Barnes, J. A.; DeRouchey, J. M.; Tokach, M. D.; Goodband, R. D.; Nelssen, J. L. and Dritz, S. S. 2011. Effects of xylanase in growing-finishing diets varying in dietary energy and fiber on growth performance, carcass characteristics, and nutrient digestibility. Kansas Agricultural Experiment Station Research Reports. p.227-239. https://doi.org/10.4148/2378-5977.7124 
Belyea, R. L.; Rausch, K. D.; Clevenger, T. E.; Singh, V.; Johnston, D. B. and Tumbleson, M. E. 2010. Sources of variation in composition of DDGS. Animal Feed Science and Technology 159:122-130. https://doi.org/10.1016/j.anifeedsci.2010.06.005

Bolarinwa, O. A. and Adeola 0. 2016. Regression and direct methods do not give different estimates of digestible and metabolizable energy values of barley, sorghum, and wheat for pigs. Journal of Animal Science 94:610-618. https://doi. org/10.2527/jas.2015-9766

Corassa, A.; Lautert, I. P. A. S.; Pina, D. S.; Kiefer, C.; Ton, A. P. S.; Komiyama, C. M.; Amorim, A. B. and Teixeira, A. O. 2017. Nutritional value of Brazilian distillers dried grains with solubles for pigs as determined by different methods. Revista Brasileira de Zootecnia 46:740-746. https://doi.org/10.1590/s1806-92902017000900005

Feoli, C.; Hancock, J. D.; Gugle, T. L.; Carter, S. D. and Cole, N. A. 2008. Effects of adding enzymes to diets with corn- and sorghum-based dried distillers grains with solubles on growth performance and nutrient digestibility in nursery and finishing pigs. Kansas Agricultural Experiment Station Research Reports. p.104-110. https://doi.org/10.4148/2378-5977.7030

Graham, A. B.; Goodband, R. D.; Tokach, M. D.; Dritz, S. S.; DeRouchey, J. M. and Nitikanchana, S. 2014. The effects of medium-oil dried distillers grains with solubles on growth performance, carcass traits, and nutrient digestibility in growing-finishing pigs. Journal of Animal Science 92:604-611. https://doi.org/10.2527/jas.2013-6798

Gomes, J. D. F.; Putrino, S. M.; Grossklaus, C.; Utiyama, C. E.; Oetting, L. L.; Souza, L. W. O.; Fukushima, R. S.; Fagundes, A. C. A. Sobral, P. J. A. and Lima, C. G. 2007. Efeitos do incremento de fibra dietética sobre a digestibilidade, desempenho e características de carcaça: I. suínos em crescimento e terminação. Semina: Ciências Agrárias 28:483-492.

Hanson, A. R.; Xu, G.; Li, M.; Whitney, M. H. and Shurson, G. C. 2012. Impact of dried distillers grains with solubles (DDGS) and diet formulation method on dry matter, calcium, and phosphorus retention and excretion in nursery pigs. Animal Feed Science and Technology 172:187-193. https://doi.org/10.1016/j.anifeedsci.2011.12.027

Jacela, J. Y.; Frobose, H. L.; DeRouchey, J. M.; Tokach, M. D.; Dritz, S. S.; Goodband, R. D. and Nelssen, J. L. 2010. Amino acid digestibility and energy concentration of high-protein corn dried distillers grains and high-protein sorghum dried distillers grains with solubles for swine. Journal of Animal Science 88:3617-3623. https://doi.org/10.2527/jas.2010-3098

Jones, C. K.; Bergstrom, J. R.; Tokach, M. D.; DeRouchey, J. M.; Goodband, R. D.; Nelssen, J. L. and Dritz, S. S. 2010. Efficacy of commercial enzymes in diets containing various concentrations and sources of dried distillers grains with solubles for nursery pigs. Journal of Animal Science 88:2084-2091. https://doi.org/10.2527/jas.2009-2109

Kerr, B. J.; Weber, T. E. and Shurson, G. C. 2013. Evaluation of commercially available enzymes, probiotics, or yeast on apparent total-tract nutrient digestion and growth in nursery and finishing pigs fed diets containing corn dried distillers grains with solubles. The Professional Animal Scientist 29:508-517. https://doi.org/10.15232/S1080-7446(15)30272-2

Kim, Y.; Mosier, N. S.; Hendrickson, R.; Ezeji, T.; Blaschek, H.; Dien, B.; Cotta, M.; Dale, B. and Ladisch, M. R. 2008. Composition of corn dry-grind ethanol by-products: DDGS, wet cake, and thin stillage. Bioresource Technology 99:5165-5176. https://doi.org/10.1016/j.biortech.2007.09.028

Lammers, P. J.; Kerr, B. J. and Honeyman, M. S. 2015. Biofuel co-products as swine feed ingredients: Combining corn distillers dried grains with solubles (DDGS) and crude glycerin. Animal Feed Science and Technology 201:110-114 https://doi.org/10.1016/j.anifeedsci.2014.12.013

Li, P.; Li, D. F.; Zhang, H. Y.; Li, Z. C.; Zhao, P. F.; Zeng, Z. K.; Xu, X. and Piao, X. S. 2015. Determination and prediction of energy values in corn distillers dried grains with solubles sources with varying oil content for growing pigs. Journal of Animal Science 93:3458-3470. https://doi.org/10.2527/jas.2014-8782

Moran, K.; Lange, C. F. M.; Ferket, P.; Fellner, V.; Wilcock, P. and van Heugten, E. 2016. Enzyme supplementation to improve the nutritional value of fibrous feed ingredients in swine diets fed in dry or liquid form. Journal of Animal Science 94:1031-1040. https://doi.org/10.2527/jas.2015-9855

Ndou, S. P.; Kiarie, E.; Agyekum, A. K.; Heo, J. M.; Romero, L. F.; Arent, S.; Lorentsen, R. and Nyachoti, C. M. 2015. Comparative efficacy of xylanases on growth performance and digestibility in growing pigs fed wheat and wheat branor corn and corn DDGS-based diets supplemented with phytase. Animal Feed Science and Technology 209:230-239. https://doi.org/10.1016/j.anifeedsci.2015.08.011

NRC - National Research Council. 2012. Nutrient requirements of swine. 11th ed. National Academy Press, Washington, DC.

Pedersen, M. B.; Dalsgaard, S.; Knudsen, K. E. B.; Yu, S. and Laerke, H. N. 2014. Compositional profile and variation of distillers dried grains with solubles from various origins with focus on non-starch polysaccharides. Animal Feed Science and Technology 197:130-141. https://doi.org/10.1016/j.anifeedsci.2014.07.011

Rostagno, H. S.; Albino, L. F. T.; Donzele J. L.; Gomes, P. C.; Oliveira, R. F.; Lopes, D. C.; Ferreira, A. S.; Barreto, S. L. T. and Euclides, R. F. 2011. Tabelas brasileiras para aves e suínos: composição de alimentos e exigências nutricionais. UFV, Viçosa, MG.

Sakomura, N. K. and Rostagno, H. S. 2016. Métodos de pesquisa em nutrição de monogástricos. FUNEP, Campinas.

Noblet, J. and Shi, X. S. 1994. Effect of body weight on digestive utilization of energy and nutrients of ingredients and diets in pigs. Livestock Production Science 37:323-338. https://doi.org/10.1016/0301-6226(94)90126-0

Silva, D. J. and Queiroz, A. C. 2002. Análise de alimentos: métodos químicos e biológicos. Editora UFV, Viçosa, MG.

R. Bras. Zootec., 48:e20190012, 2019 
Silva, J. R. 2015. Resíduo seco de destilaria contendo solúveis (DDGS), com e sem xilanase, na alimentação de cães. Dissertação (M.Sc.). Universidade Federal do Paraná, Curitiba.

Sotak, K. M.; Goodband, R. D.; Tokach, M. D.; Dritz, S. S.; DeRouchey, J. M. and Nelssen, J. L. 2014. Nutrient database for sorghum distillers dried grains with solubles from etanol plants in the western plains region and their effects on nursery pig performance. Journal of Animal Science 92:292-302. https://doi.org/10.2527/jas.2013-6599

Stein, H. H.; Lagos, L. V. and Casas, G. A. 2016. Nutritional value of feed ingredients of plant origin fed to pigs. Animal Feed Science and Technology 218:33-69. https://doi.org/10.1016/j.anifeedsci.2016.05.003

Swiatkiewicz, S. and Koreleski, J. 2007. Effect of dietary level of maize-and rye distiller dried grains with solubles on nutrient utilization and digesta viscosity in laying hens. Journal of Animal and Feed Sciences 16:668-677. https:// doi.org/10.22358/jafs/66824/2007

Swiatkiewicz, S.; Swiatkiewicz, M.; Arczewska-Wlosek, A. and Jozefiak, D. 2016. Efficacy of feed enzymes in pig and poultry diets containing distillers dried grains with solubles: a review. Journal of Animal Physiology and Animal Nutrition 100:15-26. https://doi.org/10.1111/jpn.12351

Tsai, T.; Dove, C. R.; Cline, P. M.; Ousu-Asiedu, A.; Walsh, M. C. and Azain, M. 2017. The effect of adding xylanase or $\beta$-glucanase to diets with corn distillers dried grains with solubles (CDDGS) on growth performance and nutrient digestibility in nursery pigs. Livestock Science 197:46-52. https://doi.org/10.1016/j.livsci.2017.01.008

Urriola, P. E.; Shurson, G. C. and Stein. H. H. 2010. Digestibility of dietary fiber in distillers coproducts fed to growing pigs. Journal of Animal Science 88:2373-2381. https://doi.org/10.2527/jas.2009-2227

Verussa, G. H.; Corassa, A.; Pina, D. S.; Ton, A. P. S.; Komiyama, C. M. and Teixeira, A. O. 2017. Nutritional value of glycerin for pigs determined by different methodologies. Revista Brasileira de Zootecnia 46:584-590. https://doi.org/10.1590/ s1806-92902017000700005

Weiland, S. and Patience, J. F. 2016. Xylanase effects on apparent total tract digestibility of energy and dry matter with or without DDGS at three time points over six weeks in growing pigs. Animal Industry Report: AS 662, ASL R3122. Available at: <https://lib.driastate.edu/ans_air/vol662/iss1/83>. Accessed on: Nov. 05, 2018.

Wu, F.; Johnston, L. J.; Urriola, P. E.; Hilbrands, A. M. and Shurson, G. C. 2016. Evaluation of NE predictions and the impact of feeding maize distillers dried grains with solubles (DDGS) with variable NE content on growth performance and carcass characteristics of growing-finishing pigs. Animal Feed Science and Technology 215:105-116. https://doi. org/10.1016/j.anifeedsci.2016.02.023 